DOI 10.15290/cnisk.2016.01.01.03

DR BARBARA DRAPIKOWSKA

Akademia Obrony Narodowej

\title{
Kobiety w polskiej armii - ujęcie historyczne
}

\section{Streszczenie}

Artykuł został poświęcony problematyce militarnej partycypacji kobiet w siłach zbrojnych w perspektywie historycznej. W pierwszej części przedstawiono pokrótce sylwetki kobiet bioracych udział w powstaniach narodowych (Powstanie Kościuszkowskie - 1794, Powstanie Listopadowe - 1831, Powstanie Styczniowe - 1863). Uwage skupiono zarówno na kobietach biorących udział w walce, a także świadczących usługi medyczne i logistyczne. W drugiej części zaprezentowano zaangażowanie kobiet w działania zbrojne w czasie I wojny światowej, kiedy to powstały pierwsze regularne formacje kobiece. Następnie przedstawiono udział kobiet w czynie zbrojnym w II wojnie światowej, zarówno na frontach zewnętrznych, jak i w kraju. W końcowej części sformułowano ogólne wnioski dotyczace służby wojskowej kobiet w historii Polski.

Słowa kluczowe: kobiety w wojsku • wojskowa służba kobiet • aktywność kobiet w wojsku

\section{WOMEN IN THE POLISH ARMY - HISTORICAL PERSPECTIVE}

\section{Abstract}

The article discusses the problem of women's military service in the history of Poland. The first part of the article is dedicated to women involved in national uprisings $(1794,1830,1861)$. It presents the silhouettes of women taking part in fights or medical and logistical services. The second part focuses on the participation of women in World War I. 
The article provides a description of the first regular women's military organization. The next part of the article consists of an analysis of women's contributions to the nation's defense either on the fronts in the war or in the country. It shows how many women were involved in fights or supported the Polish Army.

Keywords: women in the Army $\bullet$ women in the military $\bullet$ military participation of women

Armia od wieków uznawana była za domenę wyłącznie męską. Różne formacje militarne, tworzone na przestrzeni dziejów, skupiały w swych szeregach jedynie osoby płci męskiej, a obecność kobiet widoczna była tylko w stanach wyższej konieczności. Najczęściej w obliczu zagrożenia lub wojny i głównie w sytuacji deficytu personelu męskiego.

Najbardziej znany historyczny przykład kobiety, angażujacej się w działania wojenne, stanowi francuska bohaterka Joanna d`Arc, stanowiąca symbol rycerskości w wydaniu żeńskim. Wśród rodzimych przykładów wspomnieć należy o królowej Polski - Jadwidze, która w 1387 r. stała na czele wyprawy na Ruś Czerwoną. Wyprawa ta umożliwiła przywrócenie polskiego panowania $\mathrm{w}$ tamtejszym regionie, zajętym wcześniej przez Węgrów ${ }^{1}$.

Pierwsze wzmianki o kobietach chwytających za broń na ziemiach polskich pojawily się w kronice Galla Anonima. $Z$ przekazów średniowiecznego kronikarza wynika, że kobiety brały udział $\mathrm{w}$ walkach zbrojnych prowadzonych w czasie powstania ludowego pod wodza Masława2. Jednakże pierwsze nazwiska kobiet angażujących się w działania zbrojne pochodza dopiero $z$ XV-XVII wieku, kiedy włączały się one $\mathrm{w}$ obronę polskich twierdz podczas najazdów tureckich ${ }^{3}$.

\footnotetext{
1 A. Pieczywok, Rola $i$ znaczenie kobiet $w$ środowisku $i$ zawodzie $w$ aspekcie historycznym [w:] Kobiety w grupach dyspozycyjnych społeczeństwa. Socjologiczna analiza udziału i roli kobiet $w$ wojsku, policji oraz $w$ innych grupach dyspozycyjnych, red. K. Dojowa, J. Maciejewski, Wrocław 2007, s. 355.

2 Powstanie ludowe, które wybuchło w latach 30. XI wieku.

3 D. Wawrzykowska-Wierciochowa, Rycerki i samarytanki, Warszawa 1988, s. $16-19$.
} 
Zachowało się bardzo mało danych osobowych na temat kobiet podejmujących działania o charakterze militarnym, których bohaterskie czyny odnotowano dla potomnych. $Z$ tamtego okresu pozostało jedynie parę nazwisk, np. Beata Dolska, biorąca udział w obronie miasta Dubna, Anna Dorota Chrzanowska, określana przez D. Wawrzykowska-Wierciochowa jako (...) najgłośniejsza, bo na cała Europe rozsławiona (...) obrończyni Trembowlit, Teofilia Chmielecka, pełniąca rolę adiutanta swojego męża, zwana wilczyca kresowa ${ }^{5}$. Ponadto istnieja przekazy o nieznanej $z$ imienia pannie Wielowiejskiej, która w męskim przebraniu na czele chłopów odparła $z$ sukcesem niewielki podjazd szwedzki. Inne nazwisko, które przetrwało to Katarzyna Grudzińska, właścicielka ziemska organizująca opór przeciwko najeźdźcom szwedzkim w okolicach Podkarpacia, walcząca razem $z$ mężczyznami podczas obrony swoich ziem ${ }^{6}$.

Kilka nazwisk kobiet uczestniczacych w działaniach o charakterze orężnym wydaje się potwierdzać ich niewielkie osiagnięcia w zakresie obronności kraju. Jednakże nie należy zapominać, że okres wieków średnich, a następnie wojen Rzeczypospolitej, to czas, w którym pozycja kobiet obejmowała najniższe obszary spolecznej hierarchii, zarówno w wymiarze zawodowym, jak i rodzinnym. Kobiety postrzegane były jako mniej wartościowe społecznie jednostki, w związku z czym odmawiano im także dostępu do edukacji. Zważywszy na powyższe, zapisanie na kartach historii jakiegokolwiek nazwiska kobiecego, świadczyć mogło o wyjątkowych predyspozycjach takiej osoby. Przykłady zaangażowania kobiet w walki orężne na przestrzeni dziejów przedstawione zostana w niniejszym artykule.

Celem opracowania jest przedstawienie militarnej partycypacji kobiet w ujęciu historycznym. Rozważania zostały zawężone do

\footnotetext{
4 Ibidem, s. 21-26.

5 W. Kopaliński, Encyklopedia drugiej płci, Warszawa, s. 44, cyt. za: A. Skrabacz, Uwarunkowania historyczne służby kobiet $w$ formacjach mundurowych [w:] Slużba kobiet $w$ formacjach mundurowych $w X X I$ wieku, red. A. Skrabacz, Warszawa 2008, s. 32.

6 D. Wawrzykowska-Wierciochowa, op. cit., s. 117-118.
} 
doświadczeń polskiej armii w okresie od powstań narodowych do zakończenia II wojny światowej.

\section{Udzial kobiet w czynie zbrojnym w okresie powstań narodowych}

Udział kobiet $\mathrm{w}$ powstaniach narodowych w większości sprowadzał się do świadczenia usług sanitarnych lub logistycznych, gdyż nie akceptowano wówczas obrazu kobiety sięgającej po broń. W czasie powstania kościuszkowskiego dość powszechnym zjawiskiem były punkty opieki nad żołnierzami, organizowane przez kobiety, co można uważać za zorganizowana służbę samarytańska, do której nawoływał sam Naczelnik w Odezwie do kobiet polskich $^{7}$.

Mocną stroną działalności Kościuszki był dobrze zorganizowany wywiad w obozach wojskowych zaborców. Niebagatelną rolę odegrała w nim Magdalena Granasowa, która po wybuchu powstania sama zaproponowała Kościuszce swoje usługi wywiadowcze. Naczelnik własnoręcznie wystawił jej świadectwo o ważności jej działań, a także bezinteresowności, co przyniosło jej szacunek i podziw wśród społeczeństwa po zakończeniu działań militarnych ${ }^{8}$.

Niewiele natomiast wiadomo o zbrojnym uczestnictwie kobiet w powstaniu kościuszkowskim. W przekazach zachowały się jedynie nazwiska Tekli Lubieńskiej, która jeszcze przed powstaniem angażowała się w działalność zbrojną oraz Anieli Węgorzewskiej, opiekującej się rannymi Polakami w Wielkopolsce, która następnie wyruszyła do Warszawy, aby tam pomóc w organizacji działań powstańczych 9 .

W bitwie pod Raszynem brały udział także kobiety, walcząc $z$ bronią w ręku. Zachowały się ich nazwiska: Zofia Kodrębska, Helena Kurdanówna i Joanna Żubrowa. H. Kurdanówna plano-

7 Kościuszko, listy, odezwy, wspomnienia, zebrał H. Mościcki, Warszawa 1917, s. 48-49.

8 D. Wawrzykowska-Wierciochowa, op. cit., s. 173.

9 Ibidem, s. 170-187. 
wała nawet utworzyć oddział, składajacy się z samych kobiet, w tym celu na własną rękę werbowała młode szlachcianki. Nie ma informacji, czy owe przedsięwzięcie zakończyło się sukcesem, jednak naraziła się Austriakom. Ucieczką przed represjami było przyodzianie męskiego munduru i wstapienie w szeregi wojsk księcia Józefa Poniatowskiego ${ }^{10}$.

$Z$ tego czasu pozostała również pamięć o J. Żubrowej, dość znanej osobistości, walczącej $\mathrm{w}$ mundurze mężczyzny, którą w 1812 r. odznaczono Srebrnym Krzyżem Virtuti Militari za odwage i bohaterstwo żołnierskie. Służyła ona w jednym pułku $z$ mężem, podajac się za jego młodszego brata - Jana. Co ciekawe, Joannie nie przyznano odznaczenia od razu, kiedy wnioskowało o to jej dowództwo, uznając, że właściwsza od odznaczenia wojskowego dla kobiety będzie nagroda pieniężna, która zainteresowana pogardziła, twierdzac, że pieniądze nie były pobudką jej działań ${ }^{11}$.

Poczatki XIX wieku to okres kształtowania się instytucji markietanki. Mianem tym określano wędrowne handlarki podążające za wojskiem, trudniące się również zarobkowo naprawa mundurów, praniem, pielęgnowaniem rannych ${ }^{12}$. Musiały one jednak posiadać umiejętność posługiwania się bronią, gdyż niejednokrotnie, będąc $\mathrm{w}$ szeregach wojska, znajdowały się w polu bitwy ${ }^{13}$. W wojsku polskim, na wzór francuski, istniała specjalna instrukcja dotycząca markietanek, które zobowiązane były przestrzegać dress code, ustalonego przez władzę wojskowa. Wymagano od nich odpowiedniego stroju w barwach pułkowych. Markietanka mogła zostać tylko kobieta zamężna, której mąż służył w danej formacji14.

Jak słusznie zauważa Aleksandra Skrabacz, dopiero od okresu powstania listopadowego można mówić o szerokim udziale kobiet w walce, wcześniejsze wystapienia orężne miały jedynie cha-

\footnotetext{
10 Ibidem, s. 203-208.

11 Ibidem, s. 237.

12 M. Żebrowska, Markietanki w Powstaniu Listopadowym, [Dostęp: 20.07.2014]. Dostępny w World Wide Web: <http://www.oldartillery.pl/strona/pliki/Markietanki_w_Powstaniu_Listopadowym.pdf $>$.

13 D. Wawrzykowska-Wierciochowa, op. cit., s. 240.

14 A.M. Skałkowski, Ksią̇ę Józef, Bytom 1913, s. 54, cyt. za: M. Żebrowska, op. cit., s. 2.
} 
rakter jednostkowy. Ponieważ udział kobiet nie był formalnie uregulowanym zagadnieniem, podejmowały one walkę $\mathrm{w}$ przebraniu męskim ${ }^{15}$.

Z okresu powstania listopadowego zachowało się już parę nazwisk kobiet, które orężem wspierały wojsko. Wśród nich wymienić można Barbarę Bronisławę Czanowską, Walerię Dębicką, Mariannę Górską, Józefę Musakowską, Teklę Sobolewską, Magdalenę Wojciechowska, Mariannę Dembińska, Zofię Kodrębską. Przetrwały także przekazy o kobietach służących na Litwie, gdzie miało uczestniczyć aż 11 ochotniczek $^{16}$. W czasie powstania listopadowego trzy kobiety doczekały się odznaczenia Virtuti Militari ${ }^{17}$.

Barwna postacia była Zofia Kuderska, która służyła pod nazwiskiem Wańkowicz, pełniąc rolę adiutanta Jana Skrzyneckiego. Co ciekawe - jako Wańkowicz została odznaczona krzyżem Virtuti Militari18. Przykładem niezłomności powstańczej jest także J. Kluczycka, która wstapiła w szeregi powstańcze w 1831 r. jako Józef Kluczycki. Uczestniczyła w wielu bitwach, tj. pod Białołęką, Grochowem, Dębem Wielkiem, Ostrołęką, a także w obronie Warszawy. Po upadku powstania wyjechała do Francji i działała w polskim środowisku emigracyjnym. Następnie zgłosiła się do służby w wojnie krymskiej w 1. Pułku Dywizji Kozaków Sułtańskich 19.

Najbardziej jednak znana postacia tego okresu jest Emilia Plater. W męskim przebraniu stanęła na czele niewielkiego oddziału powstańców na Litwie, co było jej debiutem bojowym. E. Plater była dowódcą 1. kompanii 2. litewskiego pułku piechoty. Swoim adiutantem mianowała przyjaciółkę M. Prószyńską ${ }^{20}$.

15 A. Skrabacz, Kobiety $w$ obronie narodowej Polski u progu XXI wieku, Warszawa 2001 , s. 13.

16 A. Barańska, Kobiety $w$ powstaniu listopadowym 1830-1831, Lublin 1998, s. 293-301.

17 D. Wawrzykowska-Wierciochowa, op. cit., s. 223.

18 A. Barańska, op. cit., s. 248.

19 Na podstawie filmu Kobiety $w$ historii Polski - część 4 - Józefa Rostkowska, [Dostęp: 23.10.2014], Dostępny w World Wide Web: <https://www.youtube.com/ watch?v=U-xZufyZhxE $>$.

20 E. Kozłowski, M. Wrzosek, Historia Oręża Polskiego 1795-1939, Warszawa 1984, s. 719 . 
Funkcję adiutantki E. Plater pełniła także uczestniczka powstania na Litwie - podporucznik Maria Raszanowiczówna ${ }^{21}$.

$Z$ uwagi na fakt, iż na porządku dziennym było angażowanie się kobiet do pracy w lazaretach i szpitalach wojskowych, liczba takich punktów stale rosła. $\mathrm{W}$ tym celu zawiązana została nawet organizacja: Związek Dobroczynności Patriotycznej Warszawianek, a także: Dyrekcja Opieki nad Rannymi, działająca w Wielkopolsce 22 .

Z kolei powstanie styczniowe to czas, w którym obok służby samarytańskiej, która już zaczęto określać przymiotnikiem sanitarna, bądź nawet medyczna, kobiety spełniaja się coraz powszechniej w innych dziedzinach działalności powstańczej, np. w pracy wywiadowczej i kurierskiej23. Nieliczne kobiety wstępowały również w szeregi walczących powstańców, przybierając w dalszym ciagu męskie mundury. $\mathrm{O}$ tym, że obecność kobiet $\mathrm{z}$ bronia w ręku nie była wyjątkiem świadczy chociażby bitwa pod Dobra, w której zginęły 4 kobiety, walczące w oddziale Józefa Dworcza$\mathrm{ka}^{24}$.

W zakresie feminizacji oręża można wskazać także przykład klaudynek - organizacji młodzieżowej, która stanęła do służby po wybuchu powstania. Kobiety we Lwowie utworzyły Komitet Niewiast, który z czasem poszerzył swoją działalność na tyle, że sieć tej organizacji objęła teren całej Galicji25.

O udziale kobiet $\mathrm{w}$ powstaniu styczniowym zaświadczaja również wykazy aresztantów, np. wykazy aresztowanych od września do grudnia 1864 r. na terytorium Suwałk, obejmujące informacje o 230 osobach aresztowanych za udział w powstaniu styczniowym, zawieraja nazwiska 8 kobiet $^{26}$.

21 S. Majchrowski, Niezwykłe postacie z czasów powstania listopadowego, Warszawa 1984, s. 317.

22 A. Barańska, op. cit., s. 244-249.

23 A. Skrabacz, Uwarunkowania historyczne służby kobiet..., op. cit., s. 37.

24 A. J. Cieślikowa, Próby spisania historii udziału kobiet $w$ działaniach militarnych. Publikacje do 1939 r. [w:] Kobiety w wojnach o niepodległość $i$ granice 1918-1921, red. W. Rezner, Torun 2012, s. 107.

25 Kronika kobiet, oprac. pod kier. Mariana B. Michalika, Warszawa 1993, s. 351.

26 A. Matusiewicz, Uczestnicy powstania styczniowego pozostajacy pod aresztem $w$ Suwałkach $w$ drugiej pol. 1864 r. [w:] Powstanie styczniowe 1863-1864. Wal- 
Z czasów powstania styczniowego dobrze znana postacia była Henryka Pustowójtówna, pełniąca służbę w przebraniu męskim, poczatkowo jako adiutant w batalionie płk. Czachowskiego, a następnie gen. Langiewicza ${ }^{27}$. Na poczatku swojej drogi bojowej miała duże trudności $z$ uzyskaniem pozytywnej opinii w środowisku walczacych, starano się dyplomatycznie pozbyć jej $z$ obozu i zachęcić do służby pomocniczej28.

Znana postacia była także kurierka i wywiadowca powstania styczniowego - Jadwiga Prendowska, która swoje doświadczenia posłańca spisała w Moich wspomnieniach, jedynym tego typu dokumencie w kobiecej literaturze powszechnej w ówczesnej epo$\mathrm{ce}^{29}$.

Służba sanitarna działała w dalszym ciagu, przybierając coraz bardziej zorganizowany charakter. Na przełomie 1861 r. i 1862 r. powstała w Warszawie organizacja polskich kobiet, tzw. piątki, której pierwotnym celem była pomoc Polakom uwięzionym za działalność niepodległościowa i ich rodzinom. Po wybuchu powstania styczniowego piątki zajęły się wszechstronna pomoca dla walczacych stron, obejmujac swym zasiegiem cały kraj. Zakładały one i prowadziły szpitale polowe, udzielały pomocy rodzinom walczących, dostarczały także amunicję powstańcom ${ }^{30}$.

Powstania narodowe XIX wieku to czas, kiedy wiele kobiet zasilało już oddziały powstańcze, jednakże przypadki te nie były powszechnie rozgłaszane, jak uważa Stefan Majchrowski:

Kobiety ujmowały kolegów - partyzantów swym temperamentem i odwaga, a odważnych kobiet nie brakowało w tym czasie (...) O wielu zasłużonych i odważnych Polkach nie zachowała się żadna wzmianka na piśmie. (...) Już za owych czasów myszka trącił po-

ka i uczestnicy. Represje $i$ wygnanie. Historiografia i tradycja, red. W. Caban, W. Śliwowska, Kielce 2005, s. 68-70.

27 S. Kieniewicz, Powstanie styczniowe, Warszawa 1972, s. 436.

28 D. Wawrzykowska-Wierciochowa, Najdziwniejszy $z$ adiutantów. Opowieść o Annie Henryce Pustowójtównie, Warszawa 1968, s. 151 i 159.

${ }^{29}$ Kronika kobiet... op. cit., s. 351.

30 Ibidem s. 351. 
gląd, (...) że Polka, jeśli bierze do ręki broń, czyni to "zaparłszy się swego kobiecego powołania i charakteru» 31 .

\section{Udzial kobiet w czynie zbrojnym w okresie I wojny światowej}

Niezależnie od udziału kobiet w czynie zbrojnym czy służbie pomocniczej, dopiero okres I wojny światowej przyniósł pierwsze próby zorganizowanego udziału personelu żeńskiego. Jeszcze przed wojna kobiety, przynależąc do różnych organizacji (drużyny strzeleckie, Związek Młodzieży Polskiej), otrzymywały podstawowe wyszkolenie wojskowe. Wówczas wykształcił się pogląd, że służba wojskowa kobiet może być realizowana w sanitariacie, wywiadzie oraz łaczności. I takie zadania realizowały one w Legionach, Polskiej Organizacji Wojskowej oraz Ochotniczej Legii Kobiet ${ }^{32}$.

W 1913 r. powstała w Królestwie Polskim konspiracyjna organizacja Liga Kobiet Pogotowia Wojennego, a w 1914 r. w zaborze austriackim utworzono organizację o podobnym profilu - Lige Kobiet Galicji i Śląska. Współpraca obu podmiotów doprowadziła do utworzenia żeńskich oddziałów Polskiej Organizacji Wojskowej. Po ogłoszeniu mobilizacji w sierpniu 1915 r. oddziały te zostały rozwiąane na parę miesięcy $z$ uwagi na przekonanie, że kobiety należy odsunać od spraw militarnych. Postawa ta uległa zmianie już w październiku tego samego roku, kiedy ponownie Komenda Naczelna wezwała kobiety do współpracy. Pierwsza przysięgę złożyły w lutym 1916 r. oddziały żeńskie, które zostały zorganizowane w sekcje i plutony ${ }^{33}$.

W końcu okupacji istniało 18 takich komórek, skupiajacych około 800 kobiet, zwanych potocznie peowiaczkami. Zajmowały się one pracami organizacyjnymi w komendach wszystkich szczebli, ponadto pracowały w wywiadzie, gromadziły broń, pełniły

31 S. Majchrowski, op. cit., s. 195-196.

32 B. Tazbir-Tomaszewska, $Z$ historii wojskowej służby kobiet [w:] Wojskowa służba kobiet a restrukturyzacja sit zbrojnych. Rada ds. Kobiet $w$ Siłach Zbrojnych, Warszawa 2002, s. 22.

33 T. Nałęcz, Polska Organizacja Wojskowa 1914-1918, Wrocław-WarszawaKraków-Gdańsk-Łódź 1984, s. 68. 
służbę kurierską oraz przygotowywały ekwipunek do przyszłej walki. Odpowiedzialne były za paszportowe podziemie, produkujace fałszywe dokumenty oraz czuwały nad sprawnym funkcjonowaniem transportu ${ }^{34}$.

Znaczacy udział przypisuje się kobietom w zakresie udziału w akcjach wywiadowczych POW. Ze względu na brak łączności radiowej jedyna możliwością działania wywiadowczego było wówczas odbywanie podróży przez tereny opanowane przez nieprzyjaciela. Wiazało się to $z$ licznymi przypadkami utraty życia podczas prowadzenia takiej działalności. W bilansie strat osobowych sporzadzonym przez Komende Naczelna POW na Wschodzie w $1921 \mathrm{r}$. znalazło się 108 członkiń POW rozstrzelanych przez bolszewików tylko w 1920 r. Z miesiąca na miesiąc przybywało poległych kobiet. Spośród 21 orderów Virtuti Militari 16 przyznano pośmiertnie. Ponadto 87 kobiet odznaczono Krzyżem Walecznych ${ }^{35}$.

W 1915 r. rozpoczęto pracę nad formowaniem Batalionu Warszawskiego, w których uczestniczyło wiele kobiet. Pracowały one w koszarach, szyły mundury, kompletowały ekwipunek dla żołnierzy, a także wykonywały prace administracyjne. Pomimo ich zaangażowania we wrześniu Batalion ruszył na front $z$ kategorycznym zakazem przyjmowania kobiet do służby liniowej. Próbujacc ominąc formalny rozkaz, kobiety tradycyjnie już wstapiły do armii pod męskimi przebraniami. Wśród nich była jedna $z$ najbardziej znanych kobiet-żołnierzy - Wanda Gertz, która służbę rozpoczęła jako Kazimierz Żuchowicz ${ }^{36}$.

W 1918 r. we Lwowie została utworzona Milicja Obywatelska Kobiet (MOK), która dzieliła się na trzy grupy: bojową, skupiająca kobiety zobowiazane do udziału w walkach, na wypadek działań wojennych $\mathrm{w}$ mieście, następnie straż obywatelska - bez zobowiazania oraz grupę kurierską, pełniąca służbę łącznikowa między komendami wojskowymi a Miejską Strażą Obywatelska. MOK byla formacja niewojskowa, bez prawa do wynagrodzenia i zaopatrzenia, co pociagało za sobą problemy logistyczne. Dlatego głów-

34 Ibidem, s. 30, 69 i 183.

35 Ibidem, s. 73.

36 A. Nowakowska, Wanda Gertz: opowieść o kobiecie żołnierzu, Kraków 2009, s. 13. 
ne organizatorki MOK podjęły próbę przekształcenia organizacji $\mathrm{w}$ formację wojskowa. Pomysł został zaakceptowany przez władze miasta, a MOK przekształcono w Ochotniczą Legię Kobiet (OLK) ${ }^{37}$.

OLK została zlikwidowana w 1921 r., co spotkało się z dezaprobata samych kobiet. Warto jednak zaznaczyć, że była to pierwsza regularna formacja mundurowa, obejmująca służbę kobiet. Ustawodawstwo powojenne wprowadziło zakaz pełnienia służby wojskowej przez kobiety, co spotkało się ze sprzeciwem ówczesnych organizacji skupiających je, głównie Komitetu Przysposobienia Kobiet do Obrony Kraju. Doprowadziło to do podjęcia przez ówczesne władze problemu zaangażowania kobiet w sprawy związane $z$ wojskowościa, którego pomyślne rozwiązanie przypadło dopiero w obliczu kolejnego zagrożenia - II wojny światowej.

\section{Udzial kobiet w czynie zbrojnym w okresie II wojny światowej}

Wraz z narastającym prawdopodobieństwem wojny powrócono do pomysłu angażowania kobiet w działania na rzecz wojska. Już w kwietniu 1938 r. znowelizowano przepisy o powszechnym obowiazku wojennym, przyznając kobietom prawo do służby wojskowej. Obowiazująca norma mówiła, że: Kobiety podlegaja powszechnemu obowiazkowi wojskowemu $w$ razie przyjęcia tego obowiazku ochotniczo $(\ldots)^{38}$. Obowiazek taki dotyczył pełnienia służby pomocniczej i mogły go przyjać kobiety w wieku od 19 do 45 lat. Ustawodawca zapewnił im prawo do stawania przed komisja lekarska, składajaca się jedynie $z$ kobiet, a także pełnienie służby na równi $z$ mężczyznami 39 .

W marcu 1939 r. w Warszawie utworzono Pogotowie Społecznego Przysposobienia Wojskowego Kobiet (PSPWK), działające na obszarze całego kraju, przygotowujące społeczeństwo do samo-

37 A. J. Cieślikowa, Ochotnicza Legia Kobiet 1918-1922, Warszawa 1998, cyt. za: A. Skrabacz, Uwarunkowania historyczne służby kobiet..., op. cit., s. 38-39.

38 Ustawa $z$ dnia 9 kwietnia 1938 r. o powszechnym obowiązu wojennym [Dz. U. z 1939 r. Nr 20, poz. 131], art. 8 ust. 2.

39 Ibidem, art. 31, 102 i 104. 
obrony oraz pomocy wojsku w czasie wojny. Do połowy lipca gotowość do współdziałania $z$ organizacja zgłosiło 57 podmiotów skupiających łącznie ponad 700 tys. członków. Szacowano, że przed wybuchem wojny organizacja miała w swych szeregach 47 tys. członkin ${ }^{40}$.

Udział kobiet - żołnierzy był zjawiskiem szeroko rozpowszechnionym w II wojnie światowej, kojarzonym głównie jako Pomocnicza Służba Kobiet (PSK). Ochotniczki nazywane potocznie Pestkami po przeszkoleniu standardowym i specjalnościowym pełniły służbę pozafrontową w oddziałach jako kancelistki, telefonistki, telegrafistki, sanitariuszki, kierowcy samochodowi, ponadto regulowały ruch oraz prowadzily prace kulturalno-oświatowa i artystyczna wśród żołnierzy. $Z$ ochotniczek tworzono kompanie, które przydzielano poszczególnym jednostkom wojskowym ${ }^{41}$.

W celu kształcenia przyszłych kadr PSK, a także w celu otoczenia opieką osieroconą w wyniku wojny młodzież płci żeńskiej, otwarto w Karkin-Batasz (Uzbekistan) Szkołę Junaczek, która w maju 1942 r., rozkazem dowódcy Polskich Sił Zbrojnych w Jangi Jul, została oficjalnie zatwierdzona i nazwana później Szkoła Młodszych Ochotniczek ${ }^{42}$.

W dwa lata po wybuchu wojny gen. W. Anders wydał Rozkaz Dowódcy Polskich Sił Zbrojnych w ZSRR, który w swoim brzmieniu nawoływał: Wzywam wszystkich obywateli $R P$, zdolnych do noszenia broni, by spelnili swój obowiazek względem Ojczyzny $i$ wstapili pod sztandary Orła Białego ${ }^{43}$. W całej armii gen. Andersa kobiety pełniły służbę na takich samych zasadach jak mężczyźni, tj. przyjmowanie ich do wojska regulowane było przez komisje poborowe, a w dalszej służbie kobiety podlegały takim sa-

40 J. Odziemkowski, Armia i społeczeństwo II Rzeczypospolitej, Warszawa 1996, s. 116 .

41 Encyklopedia II wojny światowej, red. Kazimierz Sobczak [et al.], Warszawa 1975 , s. 489.

42 W. Biegański, Polskie Siły Zbrojne na Zachodzie 1939-1945, Warszawa 1990, s. $101-102$.

43 A. Dzierżek, Z. Galewska, I. Horbaczewska, H. Poliszewska, Pomocnicza Służba Kobiet $w$ Polskich Siłach Zbrojnych na Zachodzie 1939-1945, Londyn 1995, s. 24. 
mym przepisom, a co za tym idzie prawom i obowiązkom ${ }^{44}$. Ochotniczkom napływajacym do wojska nadawano odpowiedni przydział, a następnie kierowano do Ośrodka Zapasowego Kobiet na odpowiednie przeszkolenie. W 1942 r. cała armia Andersa została przeniesiona do Iranu, z 2924 ochotniczkami PSK łącznie 45.

Oddziały PSK tworzono także na froncie zachodnim. Na podstawie zarządzenia z 14 grudnia 1942 r. ukazał się Tymczasowy ramowy rozkaz organizacyjny o Pomocniczej Wojskowej Służbie Kobiet, który powoływał władze naczelne całej organizacji w postaci Komendy Głównej PSK z komendantką główną w Londynie Zofia Leśniowska - córka gen. Sikorskiego. W tym samym roku powołano PSK w lotnictwie, a rok później w marynarce wojennej46.

Pomocnicza Lotnicza Służba Kobiet (PLSK) była przygotowywana w brytyjskich ośrodkach szkoleniowych dla kobiet i obejmowała kurs podstawowy w Szkocji oraz kurs oficerski i podoficerski ${ }^{47}$. W lutym 1943 r. Minister Obrony Narodowej ustalił etaty dla PLSK w AP na Wschodzie, a całą nadwyżkę wynoszącą wówczas 1128 kobiet, a także nadwyżki $z$ dalszych zaciagów, polecił skierować do lotnictwa w Anglii. Do lotnictwa brytyjskiego przybyło łącznie 9 zaciagów Polek - łącznie do służby w lotnictwie zostało skierowanych 1399 kobiet $^{48}$.

Polki, po badaniu lekarskim i wypełnieniu formularza, wchodziły w ramy brytyjskiego Women's Auxiliary Air Force (WAAF). Warunki służby dla PLSK były takie same, jak dla całego WAAF. Ochotniczki po kursie rekruckim, trwajacym początkowo 5 tygodni, a później przedłużonym do 2 miesięcy, otrzymywały pełne umundurowanie WAAF $z$ naszywka POLAND ${ }^{49}$.

Wspomnieć także należy o personelu żeńskim w lotnictwie brytyjskim - ATA (Air Transport Auxiliary - Służba Rozprowadza-

44 E. M. Car, Kobiety $w$ szeregach Polskich Sit Zbrojnych na Zachodzie 19401948, Warszawa 1995, s. 34.

45 M. Maćkowska, Pomocnicza Służba Kobiet [w:] Wysiłek Zbrojny w II wojnie światowej, red. S. Biegański, A. Szkuta, Londyn 1988, s. 93-97.

46 W. Biegański, op. cit., s. 60-69.

47 Ibidem, s. 69.

48 M. Maćkowska, op. cit., s. 115-121.

49 Ibidem, s. 121-122. 
nia Samolotów), gdzie służyły trzy Polki, tj. Jadwiga Piłsudska, Stefania Wojtulanis, Anna Leska ${ }^{50}$. ATA zajmowała się dostawami samolotów $z$ lotnisk fabrycznych do jednostek bojowych na terenie Wielkiej Brytanii. Polki służące w tej służbie nie wchodziły w skład PLSK51.

Z kolei w obrębie sił morskich działała PMSK, która została ustanowiona w grudniu 1942 r. przy kierownictwie Marynarki Wojennej w Londynie. W lipcu 1944 r. całkowicie podporzadkowano ja władzom Marynarki Wojennej oraz ustalono zasady działania. Wskutek krótkiego okresu istnienia PMSK (...) ochotniczki petnity tylko prace biurowe, $w$ kuchniach, kasynach $i$ kantynach. Na morze nie mialy okazji wyplynaćs2.

Warto zaznaczyć, że moment przejścia $2 \mathrm{KP}$ na kontynent europejski pociagał za sobą również podział PSK na dwie grupy, $\mathrm{tj}$.:

- przy Dowództwie 2. Korpusu we Włoszech - oddziały PSK, liczace 1524 ochotniczki, zorganizowane były w $2 \mathrm{KP}$ i wraz z nim uczestniczyły w kampanii włoskiej. Pełniły one w większości służbę w sanitarnych ośrodkach ewakuacyjnych, szpitalach wojennych, transporcie, łączności, administracji, przy obsłudze kantyn polowych i oddziałach kwatermistrzowskich;

- przy Dowództwie AP na Wschodzie (następnie Dowództwie Jednostek Wojskowych Środkowego Wschodu), gdzie na terenie Egiptu i Palestyny pozostało 1774 ochotniczek, stanowiących trzon obsady oświatowej oraz sanitarnej53.

$Z$ obliczeń przedstawionych przez W. Biegańskiego wynika, że pod koniec wojny w całej PSK było 6700 ochotniczek ${ }^{54}$. Przyjmuje się, że PSK stanowiło 5\% stanu osobowego całych Polskich Sił Zbrojnych ${ }^{55}$. Za udział w walkach ochotniczkom przyznano:

- 13 Krzyży Walecznych,

- 2 Złote Krzyże Zasługi,

50 G. Whittel, Kobiety $w$ kokpicie. Zapomniane bohaterki drugiej wojny światowej, przeł. Ł. Golowanow, Gdańsk 2007, s. 215.

51 A. Dzierżek [et al.], op. cit., s. 165.

52 M. Maćkowska, op. cit., s. 135.

53 A. Dzierżek [et al.], op. cit., s. 56.

54 W. Biegański, op. cit., s. 69.

55 E. M. Car, op. cit., s. 63. 
- 74 Srebrne Krzyże Zasługi,

- 154 Brązowe Krzyże Zasługi

- 950 Krzyży Monte Cassino56.

Kobiety brały udział w czynie zbrojnym zarówno na frontach wojennych, jak i na terytorium kraju, wspierając działania Armii Krajowej (AK). W latach wojny gen. Stefan Rowecki po objęciu stanowiska komendanta Związku Walki Zbrojnej, a następnie AK, stwierdził, że służba, która pełnia kobiety, nie powinna być nazywana służba pomocniczą. Tak jak na obczyźnie, tak i w kraju sprawa ta spotkała się $z$ pozytywnym rozwiązaniem formalnoprawnym. W październiku 1943 r. dekret Prezydenta RP dopuścił ochotnicza służbę kobiet do pełnienia służby zasadniczej na równych prawach $z$ mężczyznami ${ }^{57}$. $Z$ kolei na frontach obowiązywał wydany w lipcu 1944 r. kolejny rozkaz organizacyjny, który utrwalał zasadę, że PSK jest czynną służbą wojskową, dzielącą się zgodnie $z$ rodzajami wojsk ${ }^{58}$.

W styczniu 1944 r. wydane zostało zarządzenie o organizacji Wojskowej Służby Kobiet (WSK), w myśl którego jednym $z$ głównych celów powołania kobiet w szeregi armii było pomnożenie sił zbrojnych w kraju poprzez ich udział w okresie działalności konspiracyjnej i powstańczej we wszystkich służbach, nie wykluczając działań bojowych 59 .

W tym czasie płeć żeńska stanowiła $10 \%$ składu osobowego AK i była obecna we wszystkich jej strukturach. Najbardziej czynnie kobiety działały $\mathrm{w}$ łączności, gdzie obejmowały także funkcje kierownicze. W specjalnym plutonie łączności kanałowej kobiety stanowiły $60 \%$ składu60. Ponadto kobiety były czynne także w kolportażu prasy i wydawnictw AK. Zarówno na czele

\footnotetext{
56 M. Maćkowska, op. cit., s. 112.

57 B. Tazbir-Tomaszewska, op. cit., s. 24-25.

58 E. M. Car, op. cit., s. 22.

59 P. Rozwadowski, Armia Krajowa u szczytu możliwości - wizje odbudowy wojska polskiego i oswobodzenia kraju w 1944 r. [w:] Historia wojskowości XX wieku. Ksiega pamiatkowa $z$ okazji 50-lecia pracy zawodowej prof. dr. hab. Lecha Wyszczelskiego, red. A. Niewęgłowska, M. Wiśniewska, Siedlce 2010, s. 374.

60 Ibidem, s. 26-27.
} 
Kancelarii Głównej Komendy Głównej AK, jak również centralnym kolportażem AK kierowały kobiety ${ }^{61}$.

Kobiety - żołnierze AK zaznaczyły swój udział także w powstaniu warszawskim (PW), w którym zorganizowane były w kobiece oddziały. Przykładem może być służba Kobiecych Patroli Minerskich, których działalność sprowadzała się do niszczenia infrastruktury okupanta oraz produkcji i transportu min i ladunków saperskich, a także broni. Co więcej, brały one także udział w budowie telefonicznych linii polowych, tuneli i barykad62.

Formacja kobieca biorąca udział w PW był także DiSK - Dywersja i Sabotaż Kobiet (Dysk) działajacy już od 1942 r. W czasie powstania oprócz akcji dywersyjnych i sabotażowych DiSK zajmował się również działalnością zwiadowczą oraz łącznościowa, sanitarna i gospodarczą63.

Swój udział w powstaniu zaznaczyły również dziewczyny ze Związku Harcerstwa Polskiego i Służby Pomocy Żołnierzowi, które działały jako łączniczki, sanitariuszki oraz przewodniczki w kanałach. Prowadziły one także gospody i świetlice żołnierskie, zapewniające wyżywienie żołnierzom oraz ludności powstańczej64.

Standardowo już udziałem kobiet stała się służba sanitarna, dla której największy problem stanowiło organizowanie punktów ratowniczo-sanitarnych i szpitali. Personel medyczny w czasie powstania warszawskiego liczył około 2 tys. osób, z czego szacuje się, że $70-80 \%$ stanowiły kobiety ${ }^{65}$.

Po upadku powstania warszawskiego na prawach jeńców ponad 2 tys. kobiet dostało się do niewoli niemieckiej, co było europejskim ewenementem, a straty wśród kobiet żołnierzy AK były wówczas szacowane na 5 tys. ofiar66.

61 B. Tazbir-Tomaszewska, op. cit., s. 25.

62 M. Klasicka, Kobiety-powstańcy warszawscy $w$ niewoli niemieckiej (19441945), Opole 2008, s. 27-29.

63 Wielka ilustrowana encyklopedia Powstania Warszawskiego, t. 4, red. Andrzej Krzysztof Kunert [et al.], Warszawa 1997, s. 83; cyt. za: Wielka ilustrowana..., s. 29.

${ }^{64}$ M. Klasicka, op. cit., s. 30.

65 Ibidem, s. 28.

66 A. Jędro, Zmiana pozycji zawodowej kobiet $w$ służbie wojskowej $w$ ciagu lat, [w:] Kobiety w grupach dyspozycyjnych..., op. cit., s. 187. 
Istotnym elementem $\mathrm{w}$ zakresie udziału kobiet $\mathrm{w}$ II wojnie światowej, jak i całej historii wojskowej służby kobiet było utworzenie w czerwcu 1943 r. Pierwszego Samodzielnego Batalionu Kobiecego im. E. Plater. Sformowany został 3 czerwca 1943 r. w Sielcach w ramach 1. Dywizji Piechoty i liczył 750 kobiet67.

W marcu 1945 r. wydano dekret o częściowej mobilizacji do służby wojskowej, który powoływał kobiety - słuchaczki wydziałów lekarskich, weterynaryjnych, dentystycznych i farmacji zarówno uczelni krajowych, jak i zagranicznych, do 35 roku życia włącznie oraz kobiety wykonujące zawody lekarzy, dentystów, techników dentystycznych, lekarzy weterynarii, magistrów farmacji i farmaceutki, prowizorów farmacji, felczerki i pielęgniarki, do 40 roku życia włącznie. Wyjątek stanowiły kobiety, które posiadaky dzieci do lat $16^{68}$.

W przededniu zakończenia wojny podjęto kolejna próbę uformowania oddziału składającego się tylko $z$ personelu żeńskiego. Latem 1945 r. utworzono przy 1. Dywizji Pancernej gen. Maczka batalion kobiecy, liczacych 600 kobiet - żołnierzy AK, wywiezionych do Niemiec po zakończeniu wojny 69 .

Ostatni Prezydent RP na uchodźctwie - Ryszard Kaczorowski - podsumował udział kobiet w czynie zbrojnym II wojny światowej, porównując go do pracy u podstaw, która w wyniku powstań narodowych spadła na owdowiałe kobiety, samotnie borykajace się $z$ trudem utrzymania rodziny. Nie dokonano tutaj gradacji ofiarności jednych i drugich, co potwierdzić moga poniższe słowa:

Do pięknego szeregu Matek-Polek, wychowujących samotnie dzieci po powstaniach narodowych, dochodzi ofiarna praca kobiet II wojny światowej. Tych, walczących $\mathrm{w}$ Kraju $z$ okupantami i tych wywożonych przemoca na Sybir. I tu i tam bija się także o życie najbliższych. Te, którym dopisało szczęście wojenne, walczą w mundurze i wnosza do zwycięstwa widoczny udział, którego Polska -

67 Encyklopedia II wojny światowej..., op. cit., s. 434.

68 Dekret nr 55 z dnia 22 marca 1945 r. o częściowej mobilizacji do służby wojskowej [Dz. U. z 1945 r. Nr 11, poz. 55], art. 1 pkt d i f oraz art. 2 pkt e.

69 Encyklopedia II wojny światowej..., op. cit., s. 499. 
(tak jak i wkładu tamtych nieumundurowanych) - zapomnieć nie może ${ }^{70}$.

\section{Podsumowanie}

Analiza funkcji pełnionych przez kobiety na rzecz obronności na przestrzeni wieków pozwoliła stwierdzić, że stopniowo rozszerzano obszary, w których funkcje te były realizowane. Poczatkowo udział kobiet sprowadzał sie jedynie do roli reprodukcyjnej - były one niezbędne do dostarczania armii nowych pokoleń żołnierzy, wychowując w duchu patriotycznym swoich synów. Tylko nieliczne $z$ nich wykraczały poza zakres tych obowiązów, gdyż armia sama w sobie od zarania dziejów miała konotacje wyłącznie męskie.

W czasie powstań narodowych można już mówić o zwiększonym udziale kobiet $\mathrm{w}$ obszarze obronności kraju, jednakże $z$ zastrzeżeniem, że realizacja zadań na rzecz wojska miała przede wszystkim charakter usług sanitarnych, logistycznych, lub co najwyżej wywiadowczych. Udział kobiet $z$ bronią $w$ ręku był społecznie nieakceptowany, w związu $z$ tym kobiety pragnace złamać ówczesne stereotypy zmuszone były założyć męskie ubranie oraz ukryć cechy płciowe. Większość $z$ nich demaskowana była dopiero $\mathrm{w}$ sytuacji odniesienia ran na polu bitwy, a pozostałe wracały po zakończeniu działań do swoich żeńskich obowiązków, nie oczekując pochwał za swoje czyny orężne.

Regularny udział kobiet w wojsku, bez konieczności maskowania kobiecości, wiąże się $z$ wybuchem I wojny światowej, w której wachlarz możliwości co do pełnienia służby został dla kobiet znacząco rozszerzony. Po zakończeniu wojny jednak zapomniano o przydatności kobiet do żołnierskiego rzemiosła i zabroniono im służby w wojsku, wydając szereg formalnych uregulowań.

Dezaprobata jednak zmniejszała się wraz z prawdopodobieństwem kolejnego kataklizmu w dziejach ludzkości, tj. II wojny światowej. Wówczas nie tylko zwrócono się formalnie do kobiet z prośbą o zasilenie szeregów wojsk, ale także one same czuły

70 R. Kaczorowski, Przedmowa [w:] A. Dzierżek [et al.], op. cit., s. 5. 
obowiązek wsparcia ojczyzny, przez co też zarówno w kraju, jak i za granica licznie wstępowały w szeregi wojska. W czasie II wojny światowej podjęto także próbę tworzenia jednostek bojowych zasilanych wyłącznie przez kobiety. $Z$ uwagi na deficyt męskiego personelu nie musiały one swojej służby ograniczać jedynie do działań zabezpieczających, ale mogły także walczyć z bronią w rę$\mathrm{ku}$.

Po zakończeniu II wojny światowej tradycyjnie już zapomniano o udziale kobiet, co znalazło wyraz w ponownej zmianie prawodawstwa, które służbę wojskowa przewidywało tylko dla mężczyzn. Zmiany w tym zakresie przyszły dopiero wraz $z$ rokiem 1989, kiedy to niektórym kobietom, zwiazanym $z$ branżą medyczną, na zasadach szczególnych umożliwiono pełnienie służby w wojsku. Zniesienie jakichkolwiek ograniczeń, a co za tym idzie, szansa na pełną, równoprawna $z$ mężczyznami realizację w zawodzie żołnierza, uzyskały kobiety w 1999 r. wraz z wejściem Polski w struktury Sojuszu Północnoatlantyckiego.

\section{Bibliografia}

\section{Źródła}

Dekret nr 55 z dnia 22 marca 1945 r. o częściowej mobilizacji do służby wojskowej [Dz. U. z 1945 r. Nr 11, poz. 55].

Kościuszko, listy, odezwy, wspomnienia, zebrał H. Mościcki, Warszawa: nakł. Gebethnera i Wolffa, 1917.

Ustawa $z$ dnia 9 kwietnia 1938 r. o powszechnym obowiazku wojennym [Dz. U. z 1939 r. Nr 20, poz. 131].

\section{Opracowania}

Barańska A., Kobiety $w$ powstaniu listopadowym 1830-1831, Lublin: Wydawnictwo TN KUL, 1998, ISBN 83-87703-11-7.

Biegański W., Polskie Siły Zbrojne na Zachodzie 1939-1945, Warszawa: Krakowa Agencja Wydawnicza, 1990, ISBN 83-03-02923-1.

Car E. M., Kobiety $w$ szeregach Polskich Sił Zbrojnych na Zachodzie 1940-1948, Warszawa: Adiutor, 1995, ISBN 83-86100-04-4. 
Dzierżek A., Galewska Z., Horbaczewska I., Poliszewska H., Pomocnicza Służba Kobiet $w$ Polskich Siłach Zbrojnych na Zachodzie 1939-1945, Londyn: Koło Kobiet Żołnierzy PSZ w W. Brytanii, 1995, ISBN 1-872286-23-2.

Encyklopedia II wojny światowej, red. Kazimierz Sobczak [et al.], Warszawa: Wydawnictwo Ministerstwa Obrony Narodowej, 1975.

Film Kobiety w historii Polski - część 4 - Józefa Rostkowska. Dostępny na: https://www.youtube.com/watch?v=U-xZufyZhxE [dostęp: 23.10.2014].

Historia wojskowości XX wieku. Ksiegga pamiątkowa z okazji 50-lecia pracy zawodowej prof. dr. hab. Lecha Wyszczelskiego, red. A. Niewęgłowska, M. Wiśniewska, Siedlce: Uniwersytet Przyrodniczo-Humanistyczny, 2010, ISBN 978-83-923429-5-3.

Kieniewicz S., Powstanie styczniowe, Warszawa: Państwowe Wydawnictwo Naukowe, 1972.

Klasicka M., Kobiety - powstańcy warszawscy $w$ niewoli niemieckiej (1944-1945), Opole: Centralne Muzeum Jeńców Wojennych, 2008, ISBN 978-83-922178-8-6.

Kobiety $w$ grupach dyspozycyjnych społeczeństwa. Socjologiczna analiza udziału i roli kobiet $w$ wojsku, policji oraz $w$ innych grupach dyspozycyjnych, red. K. Dojwa, J. Maciejewski, Wrocław: Wydawnictwo Uniwersytetu Wrocławskiego, 2007, ISBN 978-83-229-2816-5.

Kobiety w wojnach o niepodległość i granice 1918-1921, red. W. Rezner, Toruń: Fundacja Generał Elżbiety Zawackiej, 2012, ISBN 978-8388693-30-4.

Kozłowski E., Wrzosek M., Historia Oręża Polskiego 1795-1939, Warszawa: Wiedza Powszechna, 1984, ISBN 83-214-0339-5.

Kronika kobiet, oprac. pod kier. Mariana B. Michalika, Warszawa: Kronika, 1993, ISBN 83-900331-5-1.

Majchrowski S., Niezwykłe postacie z czasów powstania listopadowego, Warszawa: Ludowa Spółdzielnia Wydawnicza, 1984, ISBN 83-2053484-4.

Nałęcz T., Polska Organizacja Wojskowa 1914-1918, Wrocław: Zakład Narodowy im. Ossolińskich, 1984, ISBN 83-04-01452-1.

Nowakowska A., Wanda Gertz: opowieść o kobiecie żołnierzu, Kraków: Wydawnictwo Avalon T. Jankowski, 2009, ISBN 978-83-60448-76-2.

Odziemkowski J., Armia i społeczeństwo II Rzeczypospolitej, Warszawa: Bellona, 1996, ISBN 83-11-08506-4. 
Powstanie styczniowe 1863-1864. Walka i uczestnicy. Represje $i w y-$ gnanie. Historiografia i tradycja, red. W. Caban, W. Śliwowska, Kielce: Wydaw. Akademii Świętokrzyskiej, 2005, ISBN 83-7133-271-8.

Skrabacz A., Kobiety $w$ obronie narodowej Polski u progu XXI wieku, Warszawa: AON; 2001, ISBN 83-88062-32-8.

Stużba kobiet $w$ formacjach mundurowych $w X X I$ wieku, red. A. Skrabacz, Warszawa: Centralna Biblioteka Wojskowa im. Marszałka Józefa Piłsudskiego, 2008, ISBN 9788389875224.

Tazbir-Tomaszewska B., $Z$ historii wojskowej służby kobiet [w:] Wojskowa służba kobiet a restrukturyzacja sił zbrojnych. Rada ds. Kobiet w Siłach Zbrojnych, Warszawa 2002, ISBN 8387226513.

Wawrzykowska-Wierciochowa D., Rycerki i samarytanki, Warszawa: Wydaw. Ministerstwa Obrony Narodowej, 1988, ISBN 83-11-07523-9.

Wawrzykowska-Wierciochowa D., Najdziwniejszy $z$ adiutantów. Opowieść o Annie Henryce Pustowójtównie, Warszawa: Wydaw. Ministerstwa Obrony Narodowej, 1968.

Wielka ilustrowana encyklopedia Powstania Warszawskiego, red. Andrzej Krzysztof Kunert [et al.], Warszawa: ARS Print Production, 1997, t. 4, ISBN 83-87224-01-4.

Whittel G., Kobiety $w$ kokpicie. Zapomniane bohaterki drugiej wojny światowej, przeł. Ł. Golowanow, Gdańsk: Wydawnictwo Wiatr od Morza Michał Alenowicz, 2014, ISBN 978-83-936653-4-1.

Wojskowa służba kobiet a restrukturyzacja sił zbrojnych: Rada ds. Kobiet $w$ Siłach Zbrojnych, Warszawa: Agencja Wydawnicza ULMAK, 2002, ISBN 83-87226-51-3.

Wysiłek Zbrojny w II wojnie światowej, red. S. Biegański, A. Szkuta, Londyn: Polskie Towarzystwo Naukowe na Obczyźnie, 1988, ISBN 1-870027-26-4.

Żebrowska M., Markietanki $w$ Powstaniu Listopadowym. [Dostęp: 20.07.2014]. Dostępny w World Wide Web: <http://www.oldartillery.pl/strona/pliki/Markietanki_w_Powstaniu_ Listopadowym. pdf $>$. 